University for Business and Technology in Kosovo

UBT Knowledge Center

Nov 7th, 9:00 AM - 5:00 PM

\title{
The Human Resources Management in the Industry of Tourism and Hospitality. The Challenges and Future Perspectives
}

Sonila Berdo

University Pavaresia Vlore, sonila.berdo@unipavaresia.edu.al

Follow this and additional works at: https://knowledgecenter.ubt-uni.net/conference

Part of the Business Commons

\section{Recommended Citation}

Berdo, Sonila, "The Human Resources Management in the Industry of Tourism and Hospitality. The Challenges and Future Perspectives" (2015). UBT International Conference. 31.

https://knowledgecenter.ubt-uni.net/conference/2015/all-events/31

This Event is brought to you for free and open access by the Publication and Journals at UBT Knowledge Center. It has been accepted for inclusion in UBT International Conference by an authorized administrator of UBT Knowledge Center. For more information, please contact knowledge.center@ubt-uni.net. 


\title{
The Human Resources Management in the Industry of Tourism and Hospitality. The Challenges and Future Perspectives
}

\author{
Sonila Berdo \\ University Pavaresia Vlore; PO.Box. 4358, AL-9401, Vlore, Albania. \\ sonila.berdo@unipavaresia.edu.al
}

\begin{abstract}
The aim of this paper is to bring into consideration the actual situation of the human resources management in the industry of tourism and hospitality, the challenges this factor is going through and the possible perspectives in the future.

This study is based on the statistical data published by international authorized institutions and different studies of the field, compared and analyzed under an accurate literature review process made by the author. What comes up from this study is that eventhough the labor force of the tourism industry is the biggest ever known until now, half of it is part time employed and no qualified, dominated by students and emigrants groups who in general are low payed. In constrast to this, in most developed countries, where this industry is one of the most important regarding to income generation, happens that the service receiver- the tourist, is generally served by the low qualified employee. So, the failure or the success in this industry actually depands on the lowest payed and under evaluated part of the labour force. This industry suffers from negative perceptions regarding the employment practices, which in mostly cases are supported by evidence in fact. The phylosophy of human resources management is actually oriented toward short term objectives and responsabilites than toward long term ones like as the human resources development and its effective carrier path. This tendency needs to be changed due to the new challenges of the global tourism market development and smart tourist profile. Related to this last point this study offers recomandations.
\end{abstract}

Keywords: Tourism industry, Human resources, Employment, Tourist.

\section{Introduction}

The sector of tourism and hospitality has a crucial role in the world wide employment level, in the developed country as well as in those of developing status. According to the World Travel and Tourism Council report the number of jobs generated by this sector's activities is over 230 million jobs or 8.7 percent of jobs in the world (WTTC, 2006) ${ }^{6}$. Nowadays it is indisputable the importance of this sector in the employment quantity terms but is highly discussed and of great concern for various policy makers, business people, academics and researchers, the employment in this sector in terms of quality.

\subsection{Labor Force Features in Framework of the Tourism and Hospitality Industry}

Finding the right solutions to improve quality attributes of tourism industry employment there is necessary first of all understanding the nature of the labour force in this industry and the industry in its self.

\footnotetext{
${ }^{6}$ World Travel and Tourism Council (WTTC) (2006) Travel and Tourism Climbing New Heights: The 2006 Travel and Tourism Economic Research, at http://www.wttc.org/2006TSA/pdf/Executive\%20Summary\% 202006. pdf (accessed 1February 2014).
} 
According to MacDonald and Sirianni (1996) ${ }^{7}$, this industry is comprised mainly of two forms of service jobs: the first one deals with a large number of jobs which are low payed and requires low level of skills and the second form is represented by a smaller number of jobs that require high level of skills and generate high income. Only few number of jobs of this sector are in the middle of the above categories.

Based on diversity and complexity of labour force nature in this industry, Baum $(1995)^{8}$ emphasizes the impact of the geographical position in the way the employment in this industry is perceived and performed by designing a dual view of the industry and setting in front of each other extremes of employment attractiveness and working conditions, the status, the payment level, the professionalism level, and others like these attributes mentioned.

There is not a single definiton of the industry of tourism and hospitality which conferms again the diversity nature of it.

In one of the most succesful international attempts toward having a wide and comprehensive definition of this industry which is that used also by the Sector Skills Council of tourism and hospitality located in London (People 1st, 2006) ${ }^{9}$, the industry is conceptualized as a big one, comprised of 14 sub sectors like as hotels; bars and restaurants; night clubs; food providers; travel services; events; parks; hospitality service; tourists service; self-service catering; hostels; visitor attractions, etc.

It comes logical that the wide classification of tourism and hospitality, is accompanied by high diversity in terms of job types, in their different requirements and technics, in the required level of education, required job conditions, rules and duties the employee has to perform, its duration, etc. Baum $(1997)^{10}$ used a good example to ilustrate this mass of activities, by using the people and services range and the itinerary contacts that a person encounters when buys a package holiday. This person to achieve its objective has to interact with many agents, which proves again the wide range of sub sector that the tourism and hospitality industry does involve. So the person has to contact first of all with a travel agency, then with an insurance company; a transport to and from the airport; airport services like food, shops etc;immigration and customs service; local transport service; accomodation; local tour service; goods and services providers in the destination; destination emergency services, and other services like these. These moments through which passes the tourist called also 'as moments of truth', are in the center of the attention of all the companies of the industry to achieve the organisation effectiveness, to be succesful, to increase their competitiveness and generate higher profits (Carlzon, 1987) ${ }^{11}$.

What comes clear from the above ilustration is that plannning and performing an effective recruitment and selection process of human resources helps in choosing the best individuals who will be the primary contact points between the customer and the provider by estabilishing so a succesful and longlasting relationship with the tourist.

Beside the fact that the tourism indutry offers a high variety of jobs, it is highly dominated by small and medium enterprises which are of heteregeneous nature in terms of their competitive advantages; the ways they go through to achieve their objectives and aims; their sizes; services; ownership, employees way of management in offering higher quality level service. Due to this profile that industry has, it is indispensabile for it to develop its overall marketing strategy which depends on the strategies and processes estabilished to manage the human resources of the companies, like as those related to the recruitment and selection, perfomance evaluation, rewards management and staff trainings and its development.

\subsection{Labor Force Structure in the Industry of Tourism and Hospitality}

\footnotetext{
${ }^{7}$ MacDonald, C. and Sirianni, C. (1996) Working in the Service Society, Temple University Press

${ }^{8}$ Baum, T. (1995) Managing Human Resources in the European Hospitality and Tourism IndustryA Strategic Approach. Chapman and Hall

${ }^{9}$ People 1st (2006) Skills Needs Assessment, People 1st.

10 Baum, T. (1997) 'Making or breaking the tourist experience: the role of human resource management'

${ }^{11}$ Carlzon, J. (1987) Moments of Truth, Ballinger.
} 
There are different points of view on this issue. Wood (1997) $)^{12}$ does consider the employees of this industry as 'marginal workers' where are included women, young students, part time employees and immigrants. The International Labour Organisation (ILO, 2001) ${ }^{13}$ recognizes this industry as the biggest one ever known. Related to some statistical data on the employees of this industry, about 52 percent of the employees are part time engaged (HtF, 2003). Data from UK shows that the labours force is dominated especially by young people since about 37 percent of the labour force is under 24 years old and 58 percent of them are under 34 years old . (People 1st, 2006) ${ }^{14}$. Mostly of them are students and immigrants who are low qualified, and low payed. What is important to be emphasized is that eventhough in a well developed country like UK is, where the tourism industry is well explored and highly developed which generates high level of incomes, there are these low skills employees, low payed and poor motivated who offer the service to the receiver/ client by estabilishing a direct contact to them and affecting so the service quality perceived. It seems that, paradoxically the succes or the failure in the industry is highly depended on the low qualified part of the labour force. And, it is noticed that the number of this part of labour force is growing more and more since the immigrants and young students do agree to work under low payed conditions and flexible time schedule (Canny, $2002)^{15}$. They do perceive their employment as a casual need and short term engagement (Curtis and Lucas $(2001)^{16}$. Only 12 percent of the labour force is high qualified and do have the appropriatte level of education (People 1st, 2006) ${ }^{17}$.

In general, the tourism industry has encoutered negative perceptions regarding to the employment practises, and the facts do support this. Related to the prevalence of low skilled employees, there are some issues this industry suffers which induce this situation like as, the low payment level; large number of women involved; low prestige level covered especially by the immigrants; disparity in the development policies; lack of career structures; seasonal employment; informal recruitment and employment practises; high turn over rate; difficulties in recruiting workers and keeping motivated. According to Riley $(2000)^{18}$, eventhough he recognizes the presence of poor empolyment practices in this field, he argues that the main influencing factor on the human resources management policies in this industry is the economy. Riley (p. 119) believes that the management strategies and processes are shaped by 'the structure and the form under they live'. The actual economy models offer to decision makers just a short term perspective in the human resources management. Consequently, the human resources management is dominated by short term management reponsabilities which tends to pay attention more on the processes of recrutitment, selection and trainings than on the strategic human resources needs planning, human resources perfomance evaluation and rewards planning and the staff development and its strategic career path development.

According to DfEE (2000) ${ }^{19}$ there is a pesimistic situation of human resources management in the industry and hospitality sector which has to do with low payment level and a naive point of view 'as good' from the part of workers in this industry. A lot of employers describe the payment level and work condititions 'as good and acceptable', while on the other hand they report lot of problems on staff recruitment, lack of staff abilities and high turn over rate. Even ILO in its report confirms an inconsistency of attitudes between employers and employees in the tourism industry. Employers representatives explain the high rate of turn over as a result of the transit nature that the labour force in this industry shows, because of the workers social category like new moms and young people.

${ }^{12}$ Wood, R. C. (1997) Working in Hotels and Catering, International Thomson Press, 2nd edition.

13 International Labor Organization (2001) Human Resource Development, Employment and Globalization in the Hotel Catering and Tourism Sector, ILO.

${ }^{14}$ People 1st (2006) Skills Needs Assessment, People 1st.

15 Canny, A. (2002) 'Flexible labor? The growth of student employment in the UK', Journal of Education and Work, 15(3), 277-301.

${ }^{16}$ Curtis, S. and Lucas, R. (2001) 'A coincidence of needs? Employers and full-time students', Employee Relations, 23(1), 38-54.

${ }^{17}$ People 1st (2006) Skills Needs Assessment, People $1^{\text {st }}$.

18 Riley, M., Gore, J. and Kelliher, C. (2000) 'Economic determinism and human resource management practice in the hospitality and tourism industry', Tourism and Hospitality Research, 2(2), $118-128$.

${ }^{19}$ Department for Education and Employment (2000) Employers Skill Survey: Case Study Hospitality Sector, DfEE 
While employees representatives explains the high rate of turn over as a result of the low payment and lack of succesfull career and benefits in the future.

\section{Conclusions and Recommendations}

All the facts mention in this paper claim that hypothesis that the turism and hospitality industry remains a poor employment practices sector. There are many reasons which explain this situation of poor recruitment, selection and lack of employees motivation in this industry. Some of them are as follows: economic needs, small and medium enterprises domination of the industry, lack of employers goodwill to implement modern concepts of human resources management, special characteristics of labour market of this industry, companies that tends more to implement succesfull practises of short term objectives aiming to achieve high profits, etc. The companies do consider the human resources management costs as expenses and not as investment which in the future with increase their strategic position in the market and ensure a steady competitivenes level.

What the companies need to do is to change their phylosophy on their employees management by planning and implementing effective recruitment and selection processes, effective jobs evaluation needs, effective job performance evaluation, effective reward evaluation strategies and effective trainings and development programs. They have to be visionary and try to be consistent to their long term strategies and objectives, since the markets are changing shapes and are of no boundaries. Being surrounded by the high information technology reality, we have to do with a smarter client profile and what the companies need is high commitment of their staffs.

\section{References}

1. OBT, (2003). WTO Think Tank enthusiastically reaches consensus on frameworks for tourism destination success, Vol. 2003.

2. Hu, Yangzhou and Brent J R Ritchie (1993), Measuring destination attractiveness: A contextual approach, Journal of Travel Research, Fall, 25-34

3. Buhalis, Dimitrios (2000), "Marketing the competitive destination of the future," Tourism Management, 21 (1), 97-116.

4. Leiper, N., 1990. Tourism Systems. Massey University Press: Palmerston North, New Zealand.

5. Leiper, N., 1995. Tourism Management. Tafe Publications.

6. Dredge, D., 1999. Destination place planning and design. Annals of Tourism Research, Vol. 26, pp: 772-791.

7. Dredge, D., 2005. Local versus state-driven production of the region: regional tourism policy in the Hunter, New South Wales, Australia. In: Rainnie, A and Grobbelaar M (eds), New regionalism in Australia. Ashgate, Aldershot, UK, pp: 301 - 319.

8. Dredge, D., 2007. Local destination planning and policy. In: Dredge D and Jenkins J (eds) Tourism Policy and Planning. John Wiley, Milton, Queensland, pp. 300-335.

9. Dredge, D dhe Jenkins, J., (2003). Destination place identity and regional tourism policy. Tourism Geographies 3, pp: 425-443.

10. Dredge, D dhe Jenkins, J., (2007). Tourism Planning and Policy. John Wiley, Brisbane, Queensland.

11. Cartier, C., and Lew, A., (2005). Seductions of place: Geographical perspectives on Globalization and Touristed Landscapes. Routledge, London/New York.

12. Murphy, P.E., (1988). Community driven tourism planning. Tourism Management 9, pp: 96 104.

13. Hall, C.M., (1994). Tourism and Politics. Policy, Power and Place. John Wiley: Chichester, UK.

14. HASSAN, S.S., 2000. Determinants of market competitiveness in an environmentally sustainable tourism industry. Journal of Travel Research, 38(3), pp. 239-245.

15. LEE, Y. and CHEN, C., 2010. Examining and Comparing the Competitiveness of Tourism Industry in Cambodia and Taiwan: An Assessment from Professionals. Journal of American Academy of Business, Cambridge, 16(1), pp. 129-140. 
16. Goffi, Gianluca - Tourism destination competitiveness: theoretical models and empirical evidence. Università Politecnica delle Marche, Doctoral Thesis, 2011/2012. http://openarchive.univpm.it/jspui/handle/123456789/889

17. Li G, Song H, Cao Z, Wu DC. (2013). How competitive is Hong Kong against its competitors? An econometric study. Tourism Management, 36 (1), pp. 247-256. doi: 10.1016/j.tourman.2012.11.019

18. Ana Bobirca, Cristiana Cristureanu (2008), Analyzing Romania's competitiveness as a tourism destination, in Joseph S. Chen (ed.) Advances in Hospitality and Leisure (Advances in Hospitality and Leisure, Volume 4) Emerald Group Publishing Limited, pp.75 - 99

19. Porter, M. E. (1990). The Competitive Advantage of Nations. New York: Free Press.

20. Krugman, P. (1994a). "Competitiveness: A Dangerous Obsession.” Foreign Affairs, 73 (2): 28 44. 